\title{
$\mathrm{Rh}$ 부적합 수혈 후 수혈 전 검사에서 검출되지 않은 항-C 및 항-e 항체에 의한 급성 용혈
}

\section{Acute Hemolysis Due to Rh Antibodies Against C and e Antigens after Rh-incompatible Transfusion in a Patient, Not Detected During Pre-transfusion Testing}

\author{
김근주 · 이현지 · 오승환 · 김인숙 \\ Keun Ju Kim, M.D., Hyun-Ji Lee, M.D., Seung-Hwan Oh, M.D., In-Suk Kim, M.D. \\ 부산대학교 의과대학 양산부산대학교병원 진단검사의학과 \\ Department of Laboratory Medicine, Pusan National University School of Medicine, Pusan National University Yangsan Hospital, Yangsan, Korea
}

Pre-transfusion laboratory tests include $\mathrm{ABO}$ and RhD typing, antibody screening test, antibody identification test, and cross-matching. The objective of pre-transfusion testing is to ensure that serologically compatible blood products are administered to patients, thus preventing transfusion complications. Rhesus (Rh) system is considered the second most important after the ABO system, as Rh antigens are highly immunogenic and anti-Rh antibodies can cause hemolytic transfusion reactions (HTR) and hemolytic disease of the fetus and newborn. HTR caused by anti-Rh antibody usually results in delayed onset HTR. There is little information on whether antibodies against $\mathrm{C}$ and e antigen can elicit acute hemolytic transfusion reaction. We present here, a rare case of acute hemolytic transfusion reaction caused due to antibodies against $\mathrm{C}$ and e antigens, which were not detected during our pre-transfusion protocol.

Key Words: Anti-C, Anti-e, Acute hemolytic transfusion reaction, Pre-transfusion testing, Rh-incompatible transfusion

\section{CASE REPORT}

A 61-year-old female patient was admitted on June 12, 2019 for administration of the 5 th cycle of chemotherapy for cholangiocarcinoma. The patient had been treated with cisplatin and gemcitabine from February 2019 to May 2019. At the time of admission, investigations showed white blood cell count $9.44 \times 10^{9} / \mathrm{L}$, hemoglobin $8.1 \mathrm{~g} / \mathrm{dL}$, and platelet count $96 \times 10^{9} / \mathrm{L}$. Lactate dehydrogenase (LDH) level was above normal (961 IU/L, reference

\section{Corresponding author: Hyun-Ji Lee, M.D., Ph.D.}

(DD https://orcid.org/0000-0002-9021-5632

Department of Laboratory Medicine, Pusan National University Yangsan Hospital, 20 Geumo-ro, Mulgeum-eup, Yangsan 50612, Korea

Tel: +82-55-360-1871, Fax: +82-55-360-1880, E-mail: hilhj1120@gmail.com

Received: April 29, 2020

Revision received: July 10, 2020

Accepted: July 20, 2020

This article is available from https://www.labmedonline.org (C) 2021, Laboratory Medicine Online

(a) This is an Open Access article distributed under the terms of the Creative Commons Attribution Non-Commercial License (https://creativecommons.org/licenses/by-nc/4.0/) which permits unrestricted non-commercial use, distribution, and reproduction in any medium, provided the original work is properly cited. range 273-490). Due to the low level of hemoglobin, one unit of packed red blood cells (RBCs) was requested.

Pre-transfusion testing showed that the blood group of the patient was A and RhD positive. The patient's blood sample was screened for unexpected antibodies using a 3-cell panel $(0.8 \%$ Surgiscreen RBCs reagents 1, 2, and 3 [Ortho-Clinical Diagnostics Inc., Raritan, NJ, USA]) in the low-ionic-strength saline (LISS)/ Coombs test. The antibody screening did not reveal any unexpected antibodies; therefore, Rh-subgroup typing for C, c, E, and e antigens was not performed (Fig. 1). According to our pre-transfusion protocol, the anti-human globulin (AHG) phase of crossmatching is not required in cases that are negative for antibodies. Saline cross-matching showed compatibility between the donor RBCs and the recipient serum. Thus, the patient received Rh-random transfusion, as Rh-subgroup phenotyping was not performed. During transfusion, there were no symptoms or signs of adverse transfusion complications. Consequently, cisplatin was infused to the patient for 30 minutes. There was no complication during the administration of chemotherapy. However, one hour and 30 minutes after completion of the transfusion, and $40 \mathrm{~min}$ - 


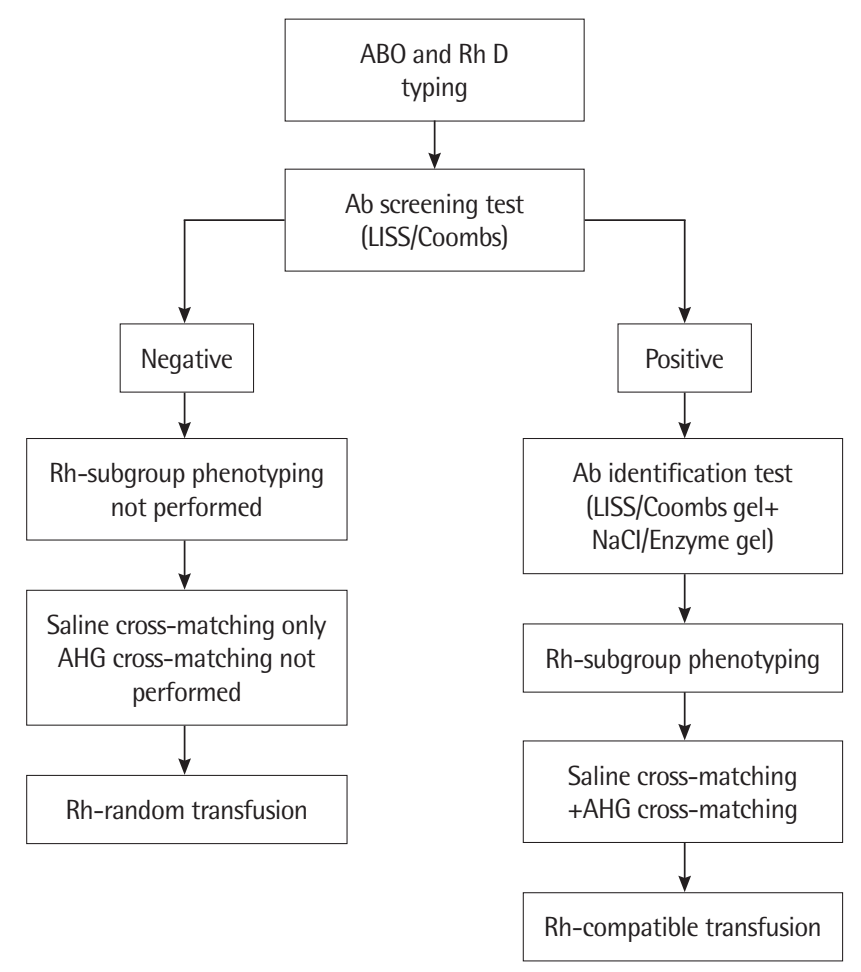

Fig. 1. The pre-transfusion protocol followed in our hospital according to the results of antibody screening.

Abbreviations: $\mathrm{Ab}$, antibody; $\mathrm{AHG}$, anti-human globulin; LISS, low-ionic-strength saline. utes after infusion of the drug, the patient complained of diaphoresis, flank pain, and hematuria. A hemolytic transfusion reaction (HTR) was suspected, and consequently the patient was administered large amounts of fluids.

A transfusion reaction workup was initiated. LDH and serum bilirubin levels were found to be increased from $961 \mathrm{IU} / \mathrm{L}$ to 1870 IU/L and $0.7 \mathrm{mg} / \mathrm{dL}$ to $2.7 \mathrm{mg} / \mathrm{dL}$, respectively. Additionally, significantly high level of cell-free plasma hemoglobin was observed $(54.8 \mathrm{mg} / \mathrm{dL}$, reference range <11). Peripheral blood smear revealed the presence of spherocytes without schistocytes. The direct antiglobulin test using polyspecific AHG (polyclonal anti-IgG and monoclonal anti-C3d) from Bio-Rad (Cressier-sur-Morat, Switzerland) was positive (1+). These findings and the clinical symp-

Table 1. Reactivity of the patient serum against representative reagent red cells

\begin{tabular}{lccc}
\hline Rh-hr & Rh genotype & LISS/Coombs & Enzyme \\
\hline CCD.ee & R1R1 & $+/-$ & $4+$ \\
cCD.EE & R2R2 & $+/-$ & - \\
Ccddee & r'r & $+/-$ & $3+$ \\
ccddee & rr & $+/-$ & $2+$ \\
Auto control & & $+/-$ & - \\
\hline
\end{tabular}

Abbreviation: LISS, low-ionic-strength saline.

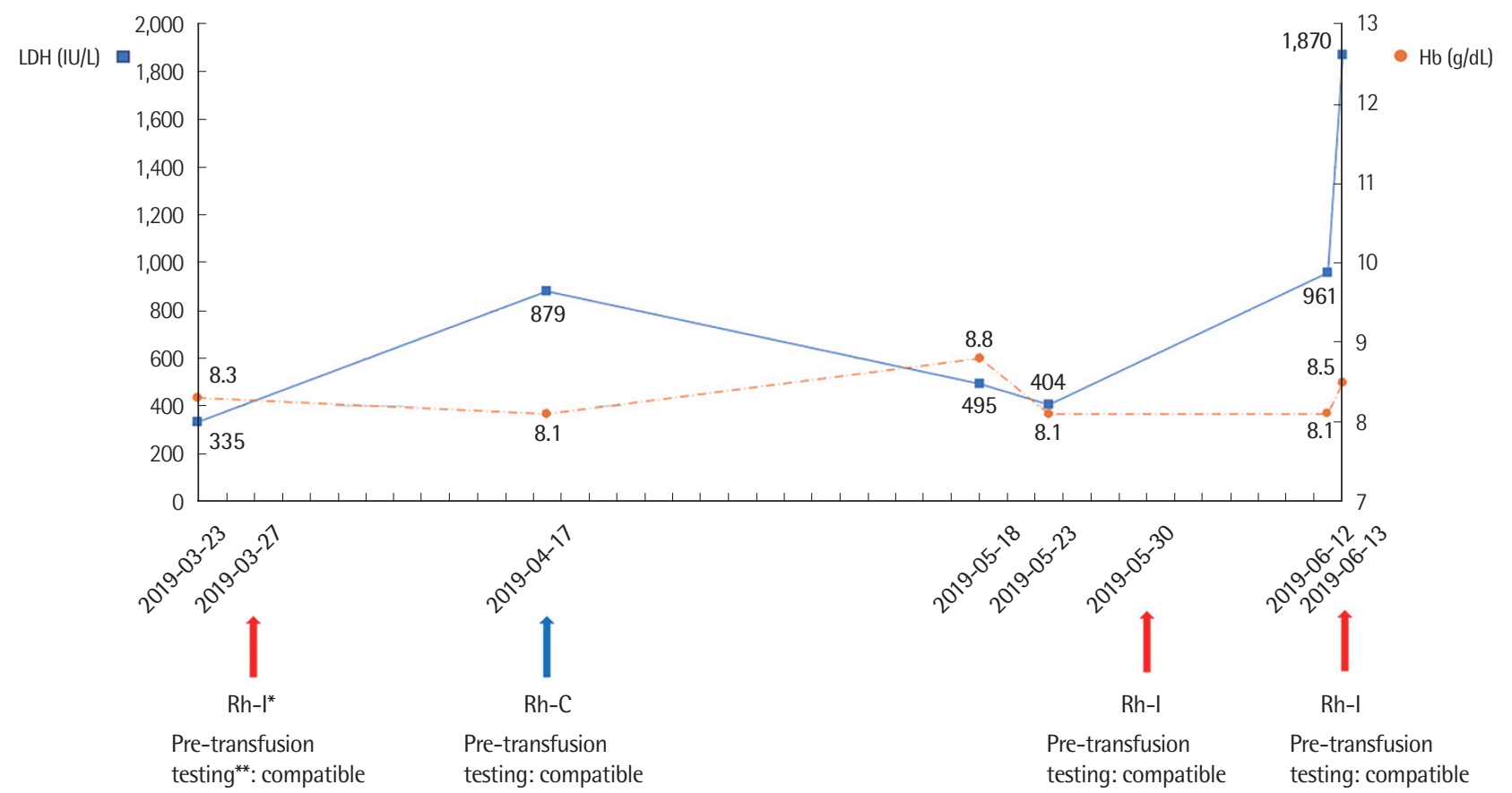

Fig. 2. Simplified laboratory values and history of multiple transfusions including antibody screening and cross-matching of the patient. ${ }^{*}$ The donor blood used in every Rh-incompatible transfusion revealed the presence of $\mathrm{C}$ and e antigen. ${ }^{* *}$ Compatible pre-transfusion testing indicates negative antibody screening and compatible saline cross-matching.

Abbreviations: LDH, lactate dehydrogenase; Hb, hemoglobin; Rh-I, Rh-incompatible transfusion; Rh-C, Rh-compatible transfusion. 
toms were suggestive of HTR.

To determine the causes of this adverse reaction, we performed additional tests using the pre-transfusion blood sample of the patient. Rh subgroup typing was performed, which revealed the presence of $\mathrm{cE}$ antigen on the RBCs of the patient. A repeat antibody screening using LISS/Coombs test from Ortho Clinical Diagnostics showed no unexpected antibodies, as observed previously. Another antibody screening using LISS/Coombs gel assay from Bio-Rad also did not reveal any unexpected antibodies. However, the $\mathrm{NaCl} /$ Enzyme gel assay revealed the presence of unexpected antibodies. Consequently, antibody identification using ID DiaPanel (Bio-Rad) was performed. 2+ reaction with rr indicated the presence of anti-e. 4+ and 3+ reactions were obtained with R1R1 and r'r, respectively, which indicated the presence of either anti-C, anti-Ce, or both along with anti-e (Table 1). Saline cross-matching again showed compatibility between the donor RBCs and the recipient serum; however, AHG cross-matching using a LISS/Coombs gel card (Bio-Rad, Cressier, Switzerland) revealed incompatibility. Since anti-Rh antibodies were present in the blood of the patient, the previous transfusion history was reviewed for Rh-compatibility (Fig. 2). Rh-incompatible transfusions had been administered thrice before, which led to the production of anti-Rh antibodies in the patient.

Diaphoresis disappeared a few hours after hydration therapy. Hematuria and flank pain resolved on the 6th day after transfusion, and the patient was discharged from the hospital. One month after discharge, the patient was admitted again and received Rh-compatible transfusion, followed by administration of cisplatin, and showed no signs and symptoms of acute hemolysis: LDH level did not increase significantly (from 410 IU/L to 442 IU/ L) and serum bilirubin remained unchanged at $0.5 \mathrm{mg} / \mathrm{dL}$. The patient did not complain of diaphoresis, flank pain, or hematuria.

\section{DISCUSSION}

Hemolytic transfusion reactions can be divided into acute and delayed hemolytic transfusion reactions [1-3]. Acute hemolytic transfusion (AHTR) reaction occurs during or within 24 hours of completion of the transfusion, whereas delayed hemolytic transfusion reaction (DHTR) occurs between 1 day and 28 days after completion of transfusion [1-3]. Most of the immune-mediated alloantibodies against Rh blood group system induce predomi- nantly extravascular hemolysis and DHTR [1, 2]. AHTR typically occurs when preformed IgM ABO antibodies attack the incompatible transfused red blood cells by complement fixation, leading to intravascular hemolysis [1, 2]. However, intravascular hemolysis and AHTR can also be triggered by non-ABO antibodies [4, 5]. Although there is no consensus on whether Rh antibodies can induce AHTR and intravascular hemolysis, sporadic cases of AHTR due to Rh antibodies have been previously reported [4, 6-11]. Rh system is the most complex among all blood group systems, and more than 49 antigens have been identified [12]. The five important Rh antigens are D, c, E, C, and e in the order of decreasing immunogenicity [4]. The Rh phenotype of the patient, in the present study, was RhDcE. The Rh phenotype of two of the three donor RBCs previously transfused to the patient was RhDCe (Fig. 1). Due to these multiple Rh-incompatible transfusions, the patient was alloimmunized to $\mathrm{C}$ and e antigens, and produced the corresponding antibodies, which remained undetected during our pre-transfusion testing. In this patient, symptoms of hematuria and flank pain were observed along with elevated LDH, bilirubin, hemoglobinemia, and spherocytes on blood smear, all of which occurred within 24 hours of completion of transfusion. In addition, direct anti-globulin test was positive (1+). Antibody identification results demonstrated the presence of anti-e (RH5) with either anti-C (RH2), anti-Ce (RH7), or both (Rh2+Rh7) (Table 1). These findings suggest AHTR due to combined Rh antibodies against $\mathrm{C}$ and e antigens. However, serologic evidences alone do not meet the "definite" criteria for AHTR according to the CDC diagnostic criteria; an elution test is necessary for confirmation of the diagnosis [3]. Hence, the diagnosis of our case is "probable" AHTR. Although cases of AHTR due to either only anti-C (RH2) [11] or only anti-e (RH5) [10] have been reported, to the best of our knowledge, AHTR due to alloantibodies against both $\mathrm{C}$ and e antigens has never been previously reported. Clinical impact caused by alloantibodies against both $\mathrm{C}$ and e antigens includes DHTR [11] and hemolytic disease of the newborn [13-17]. The impact of alloantibodies against $\mathrm{C}$ and e antigens has limited clinical significance, possibly due to the low immunogenicity of these antigens [18]. However, the present case shows a very rare significant clinical impact of the alloantibodies against $\mathrm{C}$ and e antigens.

The pre-transfusion protocol at our institution failed to detect the unexpected antibodies produced by multiple previous Rh-incompatible transfusions (Fig. 2). The culprit antibody was only 
detected by antibody screening and antibody identification using $\mathrm{NaCl} /$ Enzyme gel cards (Bio-Rad), retrospectively. This might be because the enzyme method could enhance the detection of $\mathrm{Rh}$ antibody [19]. In this patient, the early onset of HTR observed after negative screening for antibodies is unusual. The reason for this rapid hemolysis caused by the alloantibodies is difficult to elucidate [20]. In this context, it is pertinent to mention that AHTR due to Rh antibody might occur without detectable alloantibodies [6-9]. The present case adds to the evidence that 'in vitro' tests for detection of alloantibodies might not always predict the extent, if any, of RBC hemolysis 'in vivo' [11]. Despite the uncertainty, the negative result of antibody screening with the LISS/Coombs method requires further explanation. The likelihood of production of RBC antibodies by the recipient's immune system depends on various factors such as innate and acquired patient factors, the number of transfusions, and the immunogenicity of the RBC antigens [18]. Our patient suffered from cholangiocarcinoma and was consequently under chemotherapy (cisplatin). Cancer is known to induce immunosuppression [21], and cisplatin might cause bone marrow suppression [22]. Thus, it is possible that the capacity for antibody production was reduced in this patient, which might have led to low titers of the alloimmunized antibodies. In addition to this, as previously stated, the $\mathrm{C}$ and e antigens have low immunogenicity; the inherent nature of these antigens might have played a role in reducing the potency or titer of the corresponding antibodies. Unfortunately, since antibody titration was not performed and the immunoglobulin levels were not available, we were unable to test the hypotheses for the negative antibody screening. Further research to understand the antibody reaction discrepancy between the 'in vitro' and 'in vivo' is necessary.

AHTR symptoms manifested 40 minutes after completion of the 5 th cycle of cisplatin. Cisplatin is one of the most widely used anti-cancer drugs for solid tumors [22]. Anemia is thought to occur due to myelosuppression of the bone marrow by cisplatin [22]. Very rarely, acute hemolysis has been reported in a patient with a history of repeated exposure to cisplatin [23]. Thus, given the timing of the reaction and the known complication of cisplatin, it is possible that cisplatin-induced hemolysis might have occurred in our patient. Due to the lack of an elution test, as noted previously, we could not completely rule out the possibility of acute hemolysis caused by cisplatin. This is the limitation of our study. However, we believe, the fact that the patient subsequently received
Rh-compatible transfusion and cisplatin, and did not develop hemolysis, excludes the possibility of cisplatin-induced hemolysis.

The preformed $\mathrm{Rh}$ antibodies against $\mathrm{C}$ and $\mathrm{e}$ antigens in the present case were detected retrospectively using the enzyme method for antibody screening and identification, and AHG cross-matching. Subsequent Rh-compatible transfusion after full Rh-phenotyping prevented further adverse complications. These findings indicate that the current pre-transfusion protocol might miss a clinically significant alloantibody. Recipient clinical factors are known to influence the risk of RBC alloimmunization [24]. An increased risk of alloimmunization is associated with solid malignancies [25], the number of units transfused [24], hematopoietic stem cell transplantation [25], myelodysplastic syndrome [26], or hemoglobinopathy [26]. In this case, the patient suffered from solid tumor and received multiple transfusions, which are known risk factors for RBC alloimmunization. Additional pre-transfusion testing such as extended RBC phenotype can considerably reduce the risk of RBC alloimmunization in patients with hemoglobinopathy, undergoing chronic transfusion [27, 28]. Previous studies suggested that extended RBC phenotype testing might be necessary for patients with myelodysplastic syndrome who require chronic transfusion [29]. Some blood bank laboratories perform AHG cross-matching regardless of the transfusion history or antibody screening result [30]. Likewise, as the present case suggests, additional pre-transfusion testing might be beneficial in patients who have known risk factors for RBC alloimmunization, to avoid possible adverse transfusion complications. Therefore, blood bank laboratories should thoroughly assess the risk factors for RBC alloimmunization in the recipients and perform pre-transfusion testing accordingly. Additionally, clinicians should be aware of the possibility of adverse transfusion reaction in a patient despite negative antibody screening and compatible cross-matching.

In summary, the present case highlights that AHTR due to anti$\mathrm{Rh}$ antibodies against $\mathrm{C}$ and e antigens might occur without detectable antibodies. Caution should always be exercised during or after transfusion to monitor possible complications in a patient, for timely diagnosis and proper management.

\section{요 약}

검사실에서 수행하는 수혈 전 검사에는 $\mathrm{ABO}$ 및 $\mathrm{RhD}$ 혈액형 검 사, 비예기항체 선별검사 및 동정검사, 그리고 교차검사가 포함된 
다. 수혈 전 검사의 목적은 혈청학적으로 적합한 혈액을 환자에게 안전하게 수혈하여 수혈이상반응을 예방하는 것이다. Rhesus (Rh) 혈액형군은 면역원성이 아주 높고 수혈이상반응 및 신생아용혈질 환을 일으킬 수 있어 $\mathrm{ABO}$ 혈액형군 다음으로 두 번째로 중요한 혈 액형 그룹으로 간주된다. 항-Rh 항체로 인해 발생하는 용혈수혈반 응은 대개 지연성으로 발생한다. C항원과 e항원에 대한 비예기항 체가 급성용혈수혈반응을 일으키는 것에 대해서는 거의 알려진 바 가 없다. 이 증례에서 우리는 수혈 전 검사에서 검출하지 못한 C항 원과 e항원에 대한 항체에 의해 발생한 급성용혈수혈반응에 대해 기술하였다.

\section{이해관계}

저자들은 본 연구와 관련하여 어떠한 이해관계도 없음을 밝힙니다.

\section{REFERENCES}

1. Panch SR, Montemayor-Garcia C, Klein HG. Hemolytic transfusion reactions. N Engl J Med 2019;381:150-62.

2. Strobel E. Hemolytic transfusion reactions. Transfus Med Hemother 2008;35:346-53

3. Centers for Disease Control. National Healthcare Safety Network biovigilance component, hemovigilance module, surveillance protocol v2.5.2. https://www.cdc.gov/nhsn/pdfs/biovigilance/bv-hv-protocolcurrent.pdf (Last accessed on Apr, 2020)

4. Smith D, Aye T, Er LS, Nester T, Delaney M. Acute hemolytic transfusion reaction due to Anti-P1: A case report and review of institutional experience. Transfus Med Hemother 2019;46:380-3.

5. Xu Z, Duffett L, Tokessy M, Cote J, Goldman M, Saidenberg E. AntiAnWj causing acute hemolytic transfusion reactions in a patient with aplastic anemia. Transfusion 2012;52:1476-81.

6. Michalewska B, Ejduk A, Pniewska K. Acute haemolytic transfusion reaction apparently caused by the 'enzyme-only' anti-E. Vox Sang 2005; 89:61.

7. Ahn A and Hwang SH. Acute hemolytic transfusion reaction due to the "Anti-E" rhesus antibody in a patient with Crohn's disease. Clin Lab 2019;65.

8. Shmookler A, Hamad D, Scrape S, Chen J. Acute hemolytic transfusion reaction caused by a red cell antibody that was missed by pretransfusion testing using tube method. Lab Med 2017;48:258-61.

9. Pradhan D and Chaudhary R. Acute intravascular haemolytic transfusion reaction due to anti-c undetected by conventional pretransfusion cross-matching tests. Am J Hematol 1999;61:82-3.

10. Lin CK, Wong KF, Mak KH, Yuen CM, Lee AW. Hemolytic transfusion reaction due to $\mathrm{Rh}$ antibodies detectable only by manual polybrene and polyethylene glycol technique. Am J Clin Pathol 1995;104:660-2.

11. Molthan L, Matulewicz TJ, Bansal-Carver B, Benz EJ. An immediate hemolytic transfusion reaction due to anti-C and a delayed hemolytic transfusion reaction due to anti-Ce+e: hemoglobinemia, hemoglobinuria and transient impaired renal function. Vox Sang 1984;47:348-53.

12. Nardozza LM, Szulman A, Barreto JA, Araujo Junior E, Moron AF. The molecular basis of RH system and its applications in obstetrics and transfusion medicine Rev Assoc Med Bras (1992) 2010;56:724-8.

13. Sharma D, Dannapuneni N, Murki S, Pratap T. Combined anti e and anti C Rh isoimmunisation and severe hyperbilirubinemia. Indian J Pediatr 2015;82:570.

14. Sharma D and Farahbakhsh N. Neonatal hyperbilirubinemia secondary to combined anti e and anti $\mathrm{C}$ isoimmunisation: a literature review. J Matern Fetal Neonatal Med 2019;32:2009-11.

15. Ranasinghe E, Goodyear E, Burgess G. Anti-Ce complicating two consecutive pregnancies with increasing severity of haemolytic disease of the newborn. Transfus Med 2003;13:53-5.

16. Wagner T, Resch B, Legler TJ, Mossier C, Helmberg W, Köhler M, et al. Severe HDN due to anti-Ce that required exchange tranfusion. Transfusion 2000;40:571-4.

17. Malde R, Stanworth S, Patel S, Knight R. Haemolytic disease of the newborn due to anti-Ce. Transfus Med 2000;10:305-6.

18. Makarovska-Bojadzieva T, Velkova E, Blagoevska M. The impact of extended typing on red blood cell alloimmunization in transfused patients. Open Access Maced J Med Sci 2017;5:107-11.

19. Shin JH, Lee JY, Kim JH, Kim HR, Lee JN. Screening and identification of unexpected red cell antibodies by simultaneous LISS/Coombs and NaCl/Enzyme gel methods. J Korean Med Sci 2009;24:632-5.

20. Hoppe B, Pastucha L, Seltsam A, Greinacher A, Salama A. Acute haemolytic transfusion reactions due to weak antibodies that in vitro did not seem to be clinically significant. Vox Sang 2002;82:207-10.

21. Alizadeh D and Larmonier N. Chemotherapeutic targeting of cancerinduced immunosuppressive cells. Cancer Res 2014;74:2663-8.

22. Florea AM and Büsselberg D. Cisplatin as an anti-tumor drug: cellular mechanisms of activity, drug resistance and induced side effects. Cancers (Basel) 2011;3:1351-71.

23. Maloisel F, Kurtz JE, Andres E, Gorodetsky C, Dufour P, Oberling F. Platin salts-induced hemolytic anemia: cisplatin- and the first case of carboplatin-induced hemolysis. Anticancer Drugs 1995;6:324-6. 
24. Hendrickson JE. Recipient factors influencing red blood cell alloimmunization. ISBT Science Series 2020;15:194-200.

25. Bauer MP, Wiersum-Osselton J, Schipperus M, Vandenbroucke JP, Briët E. Clinical predictors of alloimmunization after red blood cell transfusion. Transfusion 2007;47:2066-71.

26. Körmöczi GF and Mayr WR. Responder individuality in red blood cell alloimmunization. Transfus Med Hemother 2014;41:446-51.

27. Singer ST, Wu V, Mignacca R, Kuypers FA, Morel P, Vichinsky EP. Alloimmunization and erythrocyte autoimmunization in transfusion-dependent thalassemia patients of predominantly Asian descent. Blood 2000;96:3369-73.
28. Lasalle-Williams M, Nuss R, Le T, Cole L, Hassell K, Murphy JR, et al. Extended red blood cell antigen matching for transfusions in sickle cell disease: a review of a 14-year experience from a single center (CME). Transfusion 2011;51:1732-9.

29. Killick SB, Carter C, Culligan D, Dalley C, Das-Gupta E, Drummond $\mathrm{M}$, et al. Guidelines for the diagnosis and management of adult myelodysplastic syndromes. Br J Haematol 2014;164:503-25.

30. Cooling L and Downs T. Immunohematology. In: Hutchison RE, McPherson RA, et al. eds. Henry's clinical diagnosis and management by laboratory methods. 23rd ed. St. Louis, MO: Elsevier, 2017:726. 